\title{
Curriculum Integration and the Semicentennial of Basil Bernstein's Classification and Framing of Educational Knowledge
}

\author{
Gary Pluim ${ }^{1}$ · Joanne Nazir ${ }^{2}$. \\ John Wallace ${ }^{3}$
}

Accepted: 12 January 2021/Published online: 15 February 2021

(C) Crown 2021

\begin{abstract}
In 1971, Basil Bernstein presented his thesis on the packaging and distribution of educational knowledge, a curricular arrangement in which its classification and framing into disciplinary categories benefited those within the hierarchical structures. In the 50 years since Bernstein's proposition, there has been a growing awareness and rejection of such disciplinary approaches in favour of integrating curricular knowledge across disciplines, not only through areas of science, math, and technology, but also across all school subjects, whereas Bernstein, and a certain strand of literature building on Bernstein's thesis, asked why and who benefits from curriculum framing, a parallel strand in the curriculum integration literature. In the following article, we re-visit Bernstein's hypothesis by examining selected interests involved in curriculum framing, but here, we specifically investigate who stands to gain when curriculum is integrated. From an extensive and persistent literature review, analysis, and collegial discussion, we cluster support of curriculum integration into six broad categories, scrutinizing each according to their major premise, aims of education, main curriculum interest(s), understanding of knowledge, and key supporters for each. We then extend this analysis by examining what interests are most salient, where and how these interests overlap, and where support for particular forms of curricular packaging is conspicuously silent. In our synthesis, we highlight a "Worldly Perspective" to curriculum delivery, an approach with potential to both deepen and broaden student learning, and which, unlike a singular disciplinary or integrated approach, is not similarly beholden to narrow interests.
\end{abstract}

Résumé En 1971, Basil Bernstein présentait sa thèse sur le formatage et la transmission des savoirs, un agencement curriculaire par lequel leur classification et leur cadrage en catégories disciplinaires profitaient à ceux qui font partie des structures hiérarchiques. Au cours des cinquante années qui se sont écoulées depuis la proposition de Bernstein, il y a eu une prise de conscience et un rejet croissant de

Gary Pluim

gpluim@lakeheadu.ca

1 Faculty of Education, Lakehead University, Orillia, Canada

2 School of Education, University of the West Indies, St. Augustine, Trinidad \& Tobago

3 Ontario Institute for Studies in Education, University of Toronto, Toronto, ON, Canada 
ces approches disciplinaires en faveur de l'intégration des savoirs curriculaires entre les disciplines, non seulement dans les domaines des sciences, des mathématiques et de la technologie, mais dans toutes les matières scolaires. Pour leur part, pendant la même période, Bernstein et un certain courant de la littérature s'appuyant sur sa thèse se demandaient à qui profite le cadrage des programmes et pourquoi, un volet parallèle de la littérature sur l'intégration curriculaire. Dans cet article, nous revoyons l'hypothèse de Bernstein en examinant certains intérêts impliqués dans le cadrage des programmes, mais dans ce cas-ci, nous examinons plus particulièrement qui peut tirer profit de l'intégration curriculaire. À partir d'un examen approfondi et persistant de la littérature, d'une analyse et d'une discussion collégiale, nous regroupons le soutien à l'intégration curriculaire en six grandes catégories, en examinant chacune d'entre elles en fonction de leur prémisse principale, de leurs objectifs éducatifs, de leurs principaux intérêts curriculaires, de la compréhension des savoirs et de leurs principaux partisans. Nous élargissons ensuite cette analyse en examinant quels intérêts sont les plus saillants, où et comment ces intérêts se chevauchent, et où le soutien à des formes particulières de formatage des programmes est ostensiblement silencieux. Dans notre synthèse, nous mettons en évidence une «perspective mondialiste » de la prestation des programmes, une approche qui pourrait permettre d'approfondir et d'élargir l'apprentissage des élèves et qui, contrairement à une approche disciplinaire ou intégrée singulière, n'est pas redevable à des intérêts étroits.

Keywords Curriculum integration $\cdot$ Curriculum studies $\cdot$ Worldly perspective $\cdot$ Democratic education $\cdot$ Environmental education $\cdot$ Sociocultural theories $\cdot$ Basil Bernstein

\section{Introduction}

We are now entering the fiftieth year since Basil Bernstein's (1971) landmark publication, "On the classification and framing of educational knowledge," an examination of how curriculum is packaged and distributed, the first of its kind. Throughout his ensuing career, Bernstein would continue to develop his ideas and cause a shift in the scholarly trajectories of curriculum studies, teaching and pedagogy, and the sociology of education (for example, Bernstein, 2000). Among Bernstein's key contributions is the proposition that, in the institutionalization of schooling hitherto, knowledge had conventionally been organized, classified, and transmitted in ways that reinforce broader structures of power and social control. In other words, curricula are not power-neutral, but fundamentally tied to politics, so that pedagogical practices resulting from them also mirror the power structures found across societies. Bernstein further classified curricula into two broad types, the first, a collection type, characterized by strong knowledge boundaries and heavy insulation between curricular topics. In this paper, instead of collection type, we use the term discipline for its convention today in educational practice and literature. The second type is integrated - where knowledge is packaged in more open relations to each other, with less insulation between contents, and fewer boundaries between subjects. In building on his notion of powerful curricula, Bernstein characterized disciplinary curriculum designs such as science and mathematics as powerful because of their vertical knowledge structures and strong framing of knowledge. Over time, this nature of knowledge argument would be used to characterize integrated curricula as weaker forms of curriculum arrangements.

As we shall explore in this paper, curriculum integration (CI) has become a common, accepted, and valued approach to curriculum classification in STEM and other education fields over the past 50 years. In response to criticisms of curricular hierarchies, the proponents of CI argue that, while the Bernsteinian notion of the powerful disciplinary paradigm reinforces traditional structures of control, a corollary argument could be applied to the weaker integrated paradigm, that is, the latter diminishes-or even 
absolves - dimensions of power and control in learning. Yet, despite this rejoinder, supporters of CI have long been dogged by the Bernsteinian censure of the inherent weakness of integrated curricula.

The overall purpose of this paper is to revisit the notions of power and knowledge structures in integrated curricula in a bid to show that the latter is also heavily steeped in invested interests and possess complex knowledge structures in order to push thinking about this type of curriculum design forward. This examination is particularly relevant as the disciplinary fields of science and mathematics education are being reconfigured as integrated STEM education (Rennie et al., 2012; Shanahan et al., 2016). Further, as the world grapples with the complex issues surrounding the Covid-19 pandemic, the Black Lives Matter movement, and other, concurrent political and social justice developments of our time, it is appearing more important than ever to (re)examine not just whether curriculum adequately addresses these issues, but how curriculum itself is packaged and delivered (see, for example, Alsop \& Hoeg, 2020; Dillon \& Avraamidou, 2020).

While this article focuses on an analysis of Bernstein's legacy, it also builds on a large body of contemporary analysis of CI by one of our authors, John Wallace, who with various co-authors, notably, and Grady Venville, have rigorously examined various vantage points, contributions, and case studies concerning the practice of integrating curriculum in the field of STEM education. Such papers have examined the dynamics of curriculum integration in classes, and the application of integrated curriculum in science-related subjects taking Bernstein's perspectives into account (see, for example, Rennie et al., 2012; Venville et al., 2008; Venville et al., 2002; Wallace et al., 2007; Wallace et al., 2010).

In doing so, we use Bernstein's work to help us interpret the analysis of the trends in curriculum integration and suggest how this might liberate the packaging of knowledge with and for students, a process that Rennie et al. (2012a, b, 2020) call a "Worldly Perspective" on curriculum.

The paper unfolds in four sections. We begin by providing some more details of Bernstein's thesis on knowledge, power, and forms of curricula. We then provide a brief background of CI as it has developed over the past 50 years. Following that, we provide our study of uncovering the ideologies of integrated curricula. We end by discussing how the pedagogical acts of framing educational knowledge may provide sound responses to the interests in curriculum classification and, in particular, highlight the possibilities of a worldly approach to curriculum.

\section{Bernstein on Knowledge, Power, and Forms of Curricula}

Bernstein's central argument, that power and control are associated with the maintenance of boundaries created by curriculum packaging in disciplinary curriculum, was a novel if not radical addition to educational thought. To that point in time, systemic analyses of curriculum and the sociology of education, more broadly, had been limited to issues of efficiency and process rather than a critical examination of the relationship between the packaging of curriculum and social relations (Bernstein, 1971). Bernstein's premise, that "...there is nothing intrinsic to the relationship between contents" (Bernstein, 1971, p. 365), asserted that educational knowledge has structures (curricular relationships) that are not arbitrarily constructed, rather, they have power and interests associated with them. Forces to maintain these boundaries came primarily from within disciplines, specifically those disciplines that held the most access to power, privilege, and control. As Bernstein suggests, these constructions are "... not simply for the transmission of educational knowledge, but for purposes of social control" (Bernstein, 1971, p. 376). Over time, as knowledge became institutionalized through schools, universities, knowledge-producing bodies, and academia, boundaries became stronger and more heavily insulated between disciplines. Bernstein referred to this organization of subject matter as disciplinary curricula, an arrangement that is familiar to most from grade school up to secondary education. 
In Curriculum Integration: Designing the Core of Democratic Education, James A. Beane (1997) would further elucidate that "subject areas are, in the end, a more severe case of "hardening of the categories' than the disciplines they supposedly represent" (p. 39). Bernstein posited that the classification and framing of educational knowledge had evolved in such a way that rigid disciplinary boundaries delineated curricular topics in collection codes, resulting in subject specific fields as a hegemonic norm in educational settings. Strong interests to preserve the collection codes within disciplines have reinforced these patterns, as opposed to using an integrated approach in packaging and disseminating curriculum.

The maintenance of disciplinary boundaries through collection codes has other effects on schooling. Beane (1997), for example, notes how disciplines are "territories carve out by academicians for their own interests and purposes" (p. 42). By extension, the preservation of subject boundaries encourages specialization, in which actors invested in specialized domains identify with and become loyal to the specialization. As Bernstein (1971) suggests, subject loyalty “...creates an educational identity which is clear-cut and bounded" (p. 373). It is natural for people to defend and protect their identity as related to their membership to a specialization. Following Bernstein, "Any attempt to weaken or change classification strength, or even frame strength, may be felt as a threat to one's identity and may be experienced as a pollution endangering the sacred" (p. 373-374). As educators become increasingly invested in a subject niche, Bernstein (1971) proposes, their tendency would naturally be to protect and promote the discipline, out of self-interest and their disciplinary community interest. It follows, therefore, that the sum of these reinforcements acts as positive feedback loops that result in the further maintenance and strengthening of disciplinary boundaries.

As strong classification promotes closed relationships, subject loyalty, and boundary maintenance, so too does it encourage a relative weighting between disciplines. As Bernstein (1971) suggests, the "stronger the classification and the framing, the more the educational relationship tends to be hierarchical and ritualized..." (p. 376). This disequilibrium in educational knowledge results in different values being placed on different school subjects. In fact, much of the scholarly extensions of Bernstein's thesis are engaged in developing empirical and theoretical justifications for inequalities of curricular status within a disciplinary structure. This literature examines more closely which disciplinary curricula (or school subjects) are given preference, why they are preferred (i.e. societal justification), and what to do about it. However, these make very significant extensions of the fundamental premises of the structure of educational knowledge. In our opinion, they do not fully resolve, Bernstein's premise, that the disciplinary curriculum enjoys higher status in all educational respects. In particular, the question of whether the integrated type curriculum garners power related to knowledge structures as well is largely unanswered. In this paper, we explore this possibility.

\section{The Rise of Curriculum Integration in the Past 50 Years}

In this section, we describe what we mean by integrated curricula and provide a brief background of work that has been going on in the area over the past 50 years. We begin by articulating what we understand by curriculum. Here we rely on Bernstein's (1971) phrasing of curricula as that which "counts as valid educational knowledge" (p. 363). It is precisely the way and the degree to which the contents of curriculum are structured that ultimately affect curricular status. High-status disciplinary subjects such as science and mathematics have contents that are clearly bounded and well-insulated from each other in closed relationships. As Bernstein (1971) points out, this arrangement denotes a strong classification system. In contrast, integrated curriculum "refers minimally to the subordination of previously insulated subjects or courses to some relational idea, which blurs the boundaries between subjects" (Bernstein, 1971, p. 371). 
Tyler (1949) suggested that integrated curricula emphasize and work with the "horizontal relationship of curriculum experiences" (p. 85). For us, simply put, curriculum integration (CI) advocates for teaching different subjects simultaneously, rather than maintaining disciplinary boundaries, as organizing frameworks for curricula. In more metaphorical terms, it is when the lines between traditional subjects become blurred-when science becomes entangled in mathematics, when literature becomes a lesson of history and when art is expressed through physical education. CI has been interrogated using various heuristics like design-based research (Gallagher \& Fazio, 2019) and concept-based curriculum frameworks (Moss et al., 2019). These authors among others suggest that curriculum integration addresses the main shortfalls of the disciplinary curriculum approach.

While it faces its share of criticism, the movement toward integration has been persistent (Wallace et al., 2007) and has generated increased momentum since the 1990s (Beane, 1997). The latter is evidenced by the growing body of literature in support of CI (see, for example, Beane, 2005; Brinegar \& Bishop, 2011; Drake, 1998; Hargreaves et al., 2002; Rennie et al., 2012a) over the past two decades. In practice, it is not uncommon in schools today to observe unit studies, term projects, and regular teaching in which material from different subjects are used together to cover curriculum expectations in STEM and other fields. Additionally, integrated methods are often showcased in media where they are lauded as the expected way school subjects are meant to be taught and the best way to prepare students for the realities of life and employment beyond schooling.

Despite the broad-based endorsement, a more minute examination of the existing body of work about CI reveals a significant gap. While several recent papers have focused on how CI manifests in classrooms or its practical benefits and hindrances, fewer papers have sought to explore in great detail, the epistemological and political issues entangled within it as suggested by Bernstein's work. For example, many readers of this paper will be familiar with Drake's (1998) classification of the six forms that integration takes in classrooms and Ross and Hogaboam-Gray's (1998) description of the benefits of $\mathrm{CI}$ on increasing student motivation, focus, and transfer of learning to everyday life. Papers that explore the more esoteric issues impacting CI tend to be of two main types: those that draw upon philosophical positions concerning the nature of knowledge to criticize CI and support the position that maintaining disciplinary boundaries among school subjects may be necessary and those that draw on newer theories from the psychology of learning such as Gestalt psychology to infer that CI supports student learning.

It is important to note that the majority of these various papers seem to be underpinned by a tacit acceptance of the dichotomous relationship between disciplinary and integrated curricula based on knowledge and power dynamics. In particular, they assume that disciplinary type curricula inherently have more powerful knowledge structures that afford them higher status, in comparison with integrated curricula (see Jacobs, 2014 for a relatively recent example). A notable exception to the latter observation is the work of Venville et al. (2002) and Rennie et al. (2012b), who have sought to illuminate how status is afforded to disciplinary arrangements through the intricacies of the grammar of schooling, and how these emerge as barriers to CI in practice. They suggest that Bernstein's characterization of $\mathrm{CI}$ is based on only one set of antecedents that do not fully consider all the possibilities inherent to educational contexts. Building on this notion, we move on to describing our investigation on illuminating the knowledge structures and power interests that lie behind integrated curricula.

\section{Illuminating the Knowledge Structures and Interests of Integrated Curricula}

The content of this section emerged out of a broader study the authors conducted with the intention of raising the level of discussion concerning CI to a more abstract level. Based on the recognition that the philosophical and sociopolitical dimensions of CI were understudied and building on the work of Wallace et al. (2010) who assessed the technical, practical, and critical interests of integration in the 
context of STEM education, we conducted an extensive review of the existing literature about CI in an attempt to map the ideological perspectives in the field.

During this process, we observed various arguments in support of CI, each with their own rationale for doing so. Over the next several months, we had numerous discussions about how we should cluster these interests into distinct groups or perspectives. While we wanted to delineate each perspective sufficiently to discern its major characteristics, we were well aware that the perspectives were not hierarchical with one being in any way better than the other. Nor did we observe (or expect) the perspectives to be entirely independent of each other. In fact, early on, we realized that the perspectives overlap with each other in various ways and to varying extents.

We settled on five criteria to help in the task of distinguishing the perspectives: major premise, aims of education, main curriculum interest(s), understanding of knowledge, and key supporters. The "major premise" criterion provided the gist or concise summary of the perspective, in our words. Drawing from the work of Dewey (1916), Miller and Seller (1985), Apple (2004), and others, the "aims of education" criterion summarized the underlying educational ideologies inherent to the perspective. The "main curriculum interest(s)" criterion for each perspective was based on Habermas' (1971) classification of curricula as having technical, practical, and critical interests. "Understanding of knowledge", summarized the epistemological underpinnings of each perspective. For this criterion, we drew upon Henderson and Kesson's (2004) notion of seven ways of knowing, traceable to early Greek thought: techne (craft reflection), polis (public moral inquiry), dialogos (multi-perspectival inquiry), poesis (soulful attunement to the creative process), praxis (critical inquiry), theoria (contemplative wisdom), and phronesis (practical deliberative wisdom). Finally, the "major supporters" criterion listed the groups that most support each perspective. Using these criteria, we were able to outline different clusters which we believe encompass the motives and ideologies of the six main perspectives supportive of CI. Through this analysis, we develop an argument that similar to interests that support disciplinary packaging and distribution of curriculum, so too do certain interests support the backing of curriculum integration.

In conducting our analysis, the following caveat shaped our thinking. We worked from a constructivist position. We began with the belief that, like all other issues, policies, and decisions in and for education, all curricula are constructed. Curriculum designers choose to delineate subjects by school discipline or to integrate. The lines between school disciplines are always drawn somewhere, based on criteria derived by someone, or by some group of decision makers. Through this constructivist lens we asked: who are the groups that speak in favour of an integrated curriculum, what interests do they support, why do they favour integration, and how structuring curriculum as integrated reinforces the beliefs and support of those who constructed it? Our work was not confined to the STEM literature, informed rather by the wider corpus of curriculum and education commentary.

The six perspectives identified are as follows: democratic, environmental, sociocultural, pragmatist, economic, and rationalist. Following is a detailed description of the ideology and of each perspective. The analysis following shows clearly how epistemology and power interests shape these perspectives.

\section{A Democratic Perspective}

As Joel Westheimer (2015) points out in What Kind of Citizen, "democracy means different things to different people, and among educators (...), the aspects of democracy that are seen as most important and the best methods for furthering these goals both vary a great deal" (p. 87). Sant (2019), in an exhaustive, recent review of over a decade of literature, proposes eight versions of democratic education, including elitist, neoliberal, liberal, deliberative, multiculturalist, participatory, critical, and agonistic. Undoubtedly, the lens one brings to the concept of democracy inextricably shapes its connection to education; and following, those interests underlying curriculum integration. One departure point for an ideal of democracy is the notion that people have voice in the decisions that most affect their lives. 
Unpacked, this proposition has ramifications on further social issues and values. Martin et al. (2008), for example, note that democracy, among its many connections, is inherently about freedom, justice, and equity. Accordingly, learning for democracy, they argue, must involve developing political literacy, working at the grassroots, and exploring alternatives.

Immanuel Kant described a democratic society as one that allows for freedom of thought, where individuals make informed decisions based on their understandings of their environments and circumstances. Kant (1992) referred to this cognitive ability as the capacity to reason and named it as an essential feature of democracy. It follows that we can only aspire to a society with the type of democracy in which people can think deeply, critically, and structurally-in order to make sound, sustainable decisions about the society in which they live-if we have individuals educated with these capacities. As Martin et al. (2008) suggest, "this means learning to argue, articulate beliefs, deliberate and come to collective decisions concerning what constitutes the good society" (p. 2), or as Habermas (1971) described, a "critical curriculum interest". This education would not be restricted to one domain, which would limit people to interest groups and thinking about their own disciplinary interests. Rather, education would be broad-based, practical, experiential, and connected to the real-world so that learners would be equipped to make decisions about the society in which they live. As such, education would not be disjoined from the society, but rather, connected to it. Just as society is complex and multi-faceted, education too would be broad-based and integrated across disciplines.

Our examination of the literature uncovered $\mathrm{CI}$ as a strategy that is heavily endorsed in democratic education. Pate and Nesin (2011), for example, discuss how they use CI for "democratic purposes" in their own teaching. Castro and Knowles (2017) investigated promising possibilities for a complex future of democratic citizenship through "a variety of disciplinary perspectives" (p. 306). Speaking of the democratic schools movement, Beane and Apple (1995) recommend the use of problem-centred, integrated approaches to interrogate complex human issues through participatory deliberation, decisionmaking, and civic action. The complexity of our increasingly globalized society, they argue, requires the kind of critical thinking that is not bounded by disciplinary parameters, but rather, learning through problem-based, democratic approaches found by integrating curriculum.

A second argument of the democratic perspective is the ensuring of relative equality in society. Dewey (1916), for example, suggests that:

A society that makes provision for participation in its good of all its members on equal terms and which secures flexible readjustment of its institutions through interaction of the different forms of associated life is in so far democratic. Such a society must have a type of education which gives individuals a personal interest in social relationships and control, and the habits of mind which secure social changes without introducing disorder. (p. 98).

This perspective is endorsed by many advocates for democracy in and for education including many critical theorists and progressive educators. For these groups, the central goal of education is developing a type of citizenship that fosters a socially just society. Critical theorists and social justice educators (see, for example, Carr, 2008; Delpit, 1995; Freire, 1970; McLaren, 1998; Sen, 2009) have emphasized the principles of equity and social justice as important concerns of the democratic society and key goals of education for modern societies that aspire to a better future for all. They suggest that many of the world's persistent problems including poverty, violence, poor health, and poor educational achievement, are rooted in the denial of basic human rights and freedoms that all people regardless of religion, race, social class, sexual orientation, and gender are entitled to. These groups advocate for education that takes on these problems through curricula built on contextually relevant issues and propose pedagogical strategies that allow for the full engagement of students in democratic political activism to solve them.

This argument suggests that integrated curricula align better than disciplinary teaching with ideals of democracy and the development of citizens to take active, positive, social, and political roles within 
their communities which in time will transform societies to make them freer, more just, and sustainable. Beane (1997), for example, suggests that "creating a curriculum for and with young people begins with an examination of the problems, issues and concerns of life as it is being lived in a real-world" (p. 40). Much earlier, Dewey proposed that an integrated education is an essential component of the antihierarchical nature of democracy (Thorburn, 2017). Through an education that integrates content matter across learning areas, equipping learners for a full and practical picture of the complexities of society, the approaches of CI would best contribute to a deeper democracy.

In summary, a democratic perspective is rooted in particular philosophical, sociological, and political understandings of the nature of the world, knowledge, and education. It is important to note, however, that this perspective directly addresses political aspects of education by strongly subscribing to a particular political theory with a particular social and ethical base. For its supporters, a democratic perspective considers and gives explicit direction to political and ethical dimensions that are often unstated in school curricula.

\section{An Environmental Perspective}

This perspective is endorsed by environmental and place-based educators, experiential educators, and many critical theorists. For these groups, the goal of education is ecocentric citizenship. Drawing upon increasing public and academic acceptance that human-caused environmental change is a real and serious threat to the well-being of life today and the continued existence of all life in the future, they assert that comprehensive programs of environmental education (EE) are necessary for students of all ages to understand and address the relationships between humans and the earth. For supporters of this perspective, integrated curricula are viewed as the ideal vehicles for encouraging students to question their relationship with the non-human world and preparing them to respond to environmental issues by taking on the role(s) of advocates, activists and stewards for the Earth (see, for example, Henderson, 2011; Linney, 2014).

Theoretically, environmental education is extremely diverse. Indeed, in compiling an inventory of the field in 2005, Sauvé suggested that there were at least 15 different approaches, or "currents" at work which could be traced to different theoretical underpinnings. This eclecticism, characteristic of EE, may be traced to its formal beginnings in the early 1970s (UNESCO, 1975) where an initial vagueness in the description of the nature of EE led to stakeholders from many orientations creating programs based on their own interpretations of it (for example, Gruenewald, 2004; Hungerford et al., 1983; Kahn, 2008; Wals et al., 2013).

Today, while much disagreement still exists within the field, two strands remain that most supporters of EE seem to agree upon. Firstly, they suggest that EE should be concerned with getting students to rethink the human-nature relationship, to see the Earth as a series of interdependent systems of which humans are a part (the ecocentric orientation) (Naess, 1988). Ecocentrism represents a significant shift in human thinking since for much of Western history the prevailing line of thought regarding the humannature relationship has been anthropocentric, with humans seeing themselves as separate from and dominant over nature (White, 1967). While all environmental educators may agree that a fundamental aspect of EE is getting students to think in more ecocentric ways, the exact nature of the shift remains a source of disagreement. For some, it is enough for students to realize that human survival is dependent on a healthy environment. Others are insistent that EE should be concerned with bringing about a deeper shift in consciousness, where the non-human world is related to as Other(s) of intrinsic worth (Nazir \& Pedretti, 2018). This second idea further suggests that EE should go beyond teaching for a conceptual shift about humans' relationship with the environment, to preparing and encouraging students to do something about contemporary environmental problems. 
Each of these strands illuminates a link between CI and EE. Although the content matter of EE is not well defined, according to Wals et al. (2013), EE requires opportunities for new types of learning which allow for "increased permeability between disciplines, generations, cultures, institutions and sectors" (p. 544). These suggested characteristics are borne out in a significant portion of the existing literature describing the successful enactment of EE. In many papers, EE is equated with dealing with an environmental issue through project work (for example, Robottom, 2012). Frequently, in addition to being multidisciplinary, these projects require students to interact with the media, politicians, and the wider community, and represent the very substance of the integrated approach to organizing curricula.

A deeper analysis of an environmental perspective reveals some points of additional interest. Firstly, because there are many different orientations of EE, knowledge has a wide range of interpretations. For advocates of this perspective, knowledge is primarily understood as a critical and moral inquiry that asks the question, "What are the underlying power structures? Whose needs are being served? How is nature being valued?" For others, knowledge also has important cultural and artistic dimensions, so that multi-perspectival inquiry and soulful attunement to the whole may also be necessary parts of the learning process. Secondly, for supporters of this perspective, the aim of education is citizenship understood in a particular way, that is, in alignment with ecocentric principles. Ecocentrism requires that people explicitly take the environment into account when living their lives. This means that being an active agent, advocate or steward of the environment is part of the responsibility of a good citizen.

Education in this perspective has an explicit political dimension. It is geared towards transforming societies into healthy sustainable places through direct human action. As such, according to Habermas' (1971) classification, the curricular interest is critical. For some, this perspective is an extension of a democratic perspective, in that it simply requires democratic considerations of equity and justice to be extended to the non-human world (Gruenewald, 2004). However, others have argued that the situation is not so simple. The crux of their argument is that democratic principles are inherently anthropocentric and antithetical to environmentalism. They are adamant that something new derived from ecocentrism is necessary as a foundation for EE (Bowers, 2008).

\section{A Sociocultural Perspective}

A sociocultural perspective, for our purposes, is one that can be said to be endorsed by the general public and holistic educators. For these groups, a main goal of education is citizenship, defined as the preparation of students for everyday living, which, in today's world, further translates into the transaction of complex societies and multiple realities. In tandem with this goal, CI is seen as a positive method of instruction that takes context and culture into account in educational situations-considerations of overriding importance for supporters of this perspective.

Supporters of a sociocultural perspective draw upon several arguments in justifying their position. A fundamental assertion is the importance of real-world connections as intrinsic features to all educational programs. In their opinion, there should be a clear link between daily life and what is taught in schools. Real-world in this context, therefore, means daily life. This notion that school should mirror students' life is not a new one. Over the years, many curriculum theorists have proposed that curricula should be drawn from the real world (for example, Bobbitt, 1918; Charters, 1923; Tyler, 1949). The crux of the reasoning behind the "real-world curriculum" is commonsensical and further supported by educators like Stevens et al. (2005), who note that in schools students do not necessarily learn through the domains of knowledge, but often, despite the intent of the planners, the curricula at school might blur together in the minds of students.

Leonardo (2004) purports that "students experience a social life that is difficult to address in disciplinary ways" (p. 3). These observations recognize how the same learners will understand different 
subjects in a myriad of ways and further suggest that advocates of this perspective are working from different understandings of the nature of education.

Indeed, advocates of a sociocultural perspective tend to draw many of their arguments from theories of holistic education. According to Miller (2007), holism is a reaction to the fragmentation which permeates all of our understandings of the world and the systems through which we commonly transact our lives and is the root cause of many of the problems facing the world today. Holism is underpinned by the idea that the world is a seamlessly interconnected whole to which we humans belong. Holistic education attempts to bring education into alignment with the notion of wholeness. It seeks to teach students how to incorporate the core principles of balance, inclusion, and connection when relating to the world. A commitment to holistic education, therefore, means that supporters of this perspective acknowledge that there are various types of knowledge and ways of learning. By this they mean, among other things, the acknowledgement that humans are made up of cognitive, physical, emotional, and spiritual aspects (Montessori, 1912; Steiner, 1965), and the importance of including these aspects in the educative process. Holistic educators often speak about taking the whole person into account during the educative process.

The latter has become increasingly important in the face of a growing body of scholarship that undermines universalist, Eurocentric notions of knowledge, teaching, and learning and the further assertion that knowledge and learning are inherently connected to culture and context (for example, Asante, 1991; Dei, 2002). Beane (1997), for his part, agrees that "the separate-subject approach carries the legacy of Western-style classical humanism that views the world in divided compartments" (p. 43). Naturally, from many Indigenous perspectives, knowledge organized in disciplinary categories was originally seen as foreign and antithetical to Indigenous worldviews (Ng-A-Fook, 2013; Smith, 1999). Because of extensive histories, traditions, and familiarity with the land, traditional stories connect local flora and fauna with social studies, morals, metaphors, and science (King, 2005; McCall et al., 2017). In Native Science: Natural Laws of Interdependence, for example, Gregory Cajete (2000) notes that nature is the basic foundation of all knowledge and this in turn is inherently linked to culture and humanity. In this way, the earth is not separate from science, from language and lore, from politics and governance. Similarly, Adekunle (2000) submits that for Indigenous African peoples learning interlinks with culture and spirituality in an integrated process that occurs in structured stages and includes the holistic emotional, intellectual and physical development of the child. This view that knowledge is culturally and contextually constructed is significantly different from positivist and scientific conceptions of knowing about our world and the knowledge often privileged in mainstream education theory. For many groups of people, worldwide knowledge has traditionally been seen as a broad, integrated phenomenon and an integrated curriculum as the best way to organize education.

A further analysis of a sociocultural perspective reveals that it shares much in common with a democratic perspective. Like the former, advocates of a sociocultural perspective view knowledge as constructed by participants and assume that strong social aspects to learning exist. However, they go a bit further in questioning the nature of knowledge, teaching, and learning.

They place more emphasis on the notion that knowledge is holistic, contextual, multi-perspectival, and culturally constructed. Poesis, or soulful attunement to the whole, is an important aspect of this epistemological construct. It is here they depart from the more political democratic and environmental perspectives. For socioculturalists, education is a process, not so much of transforming the world, but rather of helping students to interpret knowledge and find their place in the world. Citizenship, from this perspective, means being able to negotiate society competently.

Supporters view CI as particularly helpful in this process since it exposes students to multiple understandings of a topic in a holistic manner. According to Habermas' (1971) classification, the curriculum interest here, then, is practical. The emphasis lies in facilitating students to make a personal and communal sense of topics and big ideas rather than challenging ideas to any great extent. This also 
means that a sociocultural perspective lacks a strong overt political dimension. This does not mean that power dynamics are not at play in this perspective. It simply means that supporters tend to be silent about their political views, based on the belief that seeming to be apolitical is essential to commitments to holism and maintaining respect for multiple understandings of the world.

\section{A Pragmatic Perspective}

This perspective finds its supporters among many practicing educators and educational administrators, especially those who work at the primary and junior levels where teachers teach all subjects, and it is increasingly embedded in pre-service and in-service teacher training (Shriner et al., 2010). The interest of these groups in CI is primarily practical, that is, based on the mechanics, logistics, operations, and realities of the teaching environment rather than broader goals or theories of education. The argument for curriculum integration is that it works in the classroom by helping teachers to manage their workload (Wotherspoon, 2004).

In many jurisdictions internationally, teachers work with mandated curricula developed and distributed by local departments of education and/or school boards. A growing trend within these curricula that teachers often note is the tremendous volume of stated expectations that they contain. Another common observation is that traditional subject curricula often contain several repeated topics or themes. For example, the theme of food may be found in science, social studies, art, history, and reading. Supporters of a pragmatic perspective suggest that teachers may use integration to cope with this circumstance. They can address the expectations of several separate subjects by developing integrated projects based on a multi-faceted theme. This solution, according to Drake (1998), would also eliminate overlaps while simultaneously allowing "students to explore the topic from a variety of lenses that are interconnected and connected to the real-world" (p. 11). In Finland, the National Agency for Education is responding to teachers' perspectives by abandoning school subjects and adopting a phenomenon-based learning approach (Spiller, 2017).

Another strategy that some teachers use to cope with overlapping curricula is collaborative teaching. Integration acts as a foundation for this strategy by allowing teachers to co-instruct on a given theme or facilitate sub-components of the integrated unit for smaller groups of students. Another trend in many contemporary curricula is the replacement of traditional school offerings with innovative courses that may not fit neatly into the traditional disciplines (Ravetz, 2005). Indicative of this trend, the Toronto District School Board in Ontario, Canada, for example, currently offers courses with titles such as Issues in Human Rights, Green Industries, and Utopian Societies: Visions and Realities. These new courses often include new content and require the exploration of complex sets of issues with environmental, political, ethical, and global dimensions (Hanvey, 1976) - features discipline-specific teachers may not be comfortable with. Adherents of a pragmatic perspective suggest that one way for teachers to cope with these types of courses is through integrated approaches. The argument here is that integration can be used as a platform for collaboration to bring several teachers together to collectively cope with new material.

Other than coping with mandated curricula, advocates of a pragmatic perspective suggest that an integrated curriculum can help teachers address classroom diversity. The gist of this argument is that, while diversity tends to increase the complexities and intricacies of the learning environment, the differences inherent to diversity should be viewed as opportunities to enhance learning and meaningfully engage learners (Stronge, 2002). Indeed, this heightened level of engagement has been observed by researchers (see, for example, Drake, 1998; Applebee et al., 2007; Brown, 2011) observing the enactment of integrated curricula. For Court (1991), this increased engagement in learning can be explained by the capacity of integrated curricula to incorporate elements that make teaching and learning more interesting to students: 
To varying degrees, students are uninterested in school, and many seem at an early age to be bereft of the optimism and active intelligence that we associate with youth. Many young people leave school prematurely and drive through life, their potential unfulfilled. 'Integration', across subjects, from year to year and with students' outside interests, is supposed to help address this profound existential problem. (p. 118, emphasis added).

As discussed above, from a pragmatic perspective, curriculum integration is viewed in a purely utilitarian way of, "What works in the classroom?" This approach emphasizes the role of practical conditions in guiding teachers' work as opposed to drawing on abstract principles or theories of education to do so. For many practicing educators, this stance makes sense. Their sympathies seem to align with Joseph Schwab and William Rainey's (1970) call for educators to return to the practical that is, analysis of what actually happens in classrooms in designing and enacting curricula. Recent studies corroborate this rationale. For example, Ollila and Macy (2019) have seen that, since the No Child Left Behind Act, teachers integrate peripheral subject areas such as social studies into other core, standardized-test subject areas to ensure that students continue to gain civic competencies. Moss et al. (2019) found that primary and secondary school teachers use CI as a means to respond to set the learning in the context of the school, the community, and the students' diverse needs.

However, while a focus on the practical is the defining feature of this perspective, seen in another light, a pragmatic perspective's lack of theoretical backing is interpreted by some as its great weakness. For critics, it means the perspective lacks gravitas. Other than supporting a view of knowledge that is highly contextual and primarily derived from direct experience and craft reflection (techne), it is unclear what curricular interest, goal(s) for education, and broader sociopolitical stance(s) supporters of a pragmatic perspective hold. This means that, while these educators may be working from highly idealistic bases, their silence or lack of expansion about their underlying purposes and commitments may undermine their work. Their use of CI may be interpreted as callow and instrumental and leave them open to the possibility of being unwittingly used by those with narrow sociopolitical agendas. For example, a curriculum based on consideration of the practical only may become a vehicle for hegemony and stagnation of societies.

\section{An Economic Perspective}

An economic perspective might be said to be one that looks at curriculum integration as an educational approach seen as a solution to current and future demands of the job market. This perspective would be founded within ideologies that favour market-based approaches, held by groups such as government officials and business communities in economically competitive, jurisdictions categorized as neoliberal political economies. As with the pragmatic perspective, the interest of these groups is primarily practical. However, while pragmatists are focused on the needs of teachers in classrooms, supporters of an economic perspective formulate their arguments by linking the needs of society to unique interpretations of the goals of education and the nature of CI. According to these groups, the root causes of all of the problems of society are economic. Sustained economic growth is the solution required for sustained societal development. The goal of education, then, is to help in meeting this overwhelming societal need by preparing and certifying students in the knowledge, attitudes, and skills required for supporting economic growth. Advocates of this perspective suggest that CI supports this educational goal because of its focus on bringing real-world material into classrooms. By further interpreting real-world to mean workplace, adherents of an economic perspective suggest that CI supports economic growth by supplying graduates who are workplace or vocationally ready.

Many would argue that the STEM education movement is rooted in a strong economic, neoliberal rationalization (Carter, 2017). 
As has been hinted above, an economic perspective is backed by the powerful ideology of neoliberalism, which has been taken up by many of the world's developed and rapidly developing countries. Neoliberalism is a term that was introduced in the late 1930s. It represents a powerful set of ideas that, over the years, were used to change classic liberal economic theories (Mirowski \& Plehwe, 2009). Keeping the idea that economics is the key to development, neoliberal thinkers like Friedrich Hayek and Milton Friedman proposed a series of laissez-faire economic policies including free trade, open markets, privatization, deregulation, decreasing the size of the public sector, and increasing the size of the private sector as key reforms needed to ensure long-term economic success (see, among others, Harvey, 2005; Steger \& Roy, 2010). In the governance of a neoliberal political economy, the political will is most often directed by the overriding principle of ensuring competitive economic growth of its jurisdiction.

One sociological feature of neoliberal ideology is its endorsement of a human capital view of people in a society. Human capital theory (Becker, 1993) views people mechanistically as resources or raw materials available for use by the economic system. Education is seen as a way to develop these human resources by imparting the attributes most in demand at any given time to facilitate their efficient input into the growing economic system. In other words, a neoliberal political perspective favours a direct relationship between curriculum content and productive capacity.

Supporters of an economic perspective use both inferential reasoning and empirical evidence to suggest that the use of integrated curricula is best for producing graduates with the necessary capacities to foster economic growth. In constructing their arguments, they often interpret terms in specific ways to suit their broader agenda. For example, they translate the term real-world knowledge, often listed as an important component of CI, to mean qualities urgently needed for the workplace to sustain economic growth. Hunter (2011) calls these "employability skills". Supporters of an economic perspective further suggest the use of integrated approaches will ensure the development of employability skills. In terms of empirical evidence to support this link, purveyors of this perspective point to studies that demonstrate that CI, as an instructional method, produces results on standardized tests, especially those that test for competence in essential skills, which are just as good as or better than traditional discipline-based instructional methodologies (see, for example, Applebee et al., 2007; Morreale \& Zile-Tamsen, 2017; Park et al., 2017; Vars, 1991).

A deeper analysis of an economic perspective reveals an understanding of knowledge as skills (techne), and essential skills as universal pre-determined quantities that students need to be acculturated into, for the economic welfare of the society as a whole. These interpretations of educational content betray an understanding of curriculum as transmissive, and a curricular interest that Habermas (1971) would categorize as technical. While a technical interest in education is not unique, an economic perspective is deeply different from several other CI perspectives described in this paper. Where others tend to be silent or indifferent with respect to their political views, an economic perspective is explicit. Neoliberalism has a significant political agenda - to decrease government intervention, thereby increasing free-market capitalism, and often in turn, the wealth and power of individuals and states both nationally and internationally. This agenda takes a mechanistic view of society, in which people are seen (and often treated) as variables or resources in the economic system.

Education then becomes the means to this greater political end. While neoliberals argue that if put into practice, their ideas will ultimately lead to the well-being of all individuals in society, others strongly disagree. With respect to education, the argument has been broached that tailoring education to meet the economic needs of the society, as suggested by supporters of the neoliberal economic perspective, leads to erosion in the quality of education offered (Bowles \& Gintis, 1975). Placing the lion's share of emphasis on outfitting students with employability skills leads to expanded programs of technical skills training being offered to the majority of students, at the expense of the development of autonomous, deeply creative individuals. Some have even suggested that the neoliberal agenda acts as a segregating, stratifying process which maintains deeply inequitable class structures in society (see, for example, Giroux, 1983). 


\section{A Rationalist Perspective}

A rationalist perspective is endorsed by scholars and educators who take a more egalitarian view of development and a more cognitive view of education. For these groups, education is an ultimate good in itself-the key to unlocking the potential of people to reason and become wise individuals capable of leading good lives. The goal of education here is proficiency in the processes of higher order thinking and deep learning of complex concepts garnered by rational and empirical means. Advocates of this perspective believe that these latter will facilitate the development of autonomous people and over time fuel the long-term growth of societies. The gist of their argument is that CI, with its focus on framing curricula around big ideas, inherently promotes these goals.

This perspective reaches deeply into the nature of knowledge and the potential of learning. Philosophically, its roots can be traced to the ancient Greek and Enlightenment thinkers who believed that reason is a unique capacity of humans, and the principal way to attaining truth, knowledge, and wisdom. Inherent to this line of thinking are the notions that true knowledge is universal, and that all humans, despite culture and context, have the capacity to reason, and the capability to acquire it (Cassirer, 1951). The main purpose of education then is to cultivate the rational mind to discern the truths of nature (Hutchins, 1953). Based on the work of Hutchins and other influential thinkers such as Jerome Bruner and David Ausubel, a rationalist perspective builds on the root metaphors of privileging learning as mainly a cognitive, intellectual process, the universal nature of knowledge, and the cultivating deep learning of complex concepts through deep thinking. Reflecting this view, Bruner (1984) noted that "knowing how something is put together is worth a thousand facts about it. It permits you to go beyond it" (p. 183).

Arguing for the view that learning is primarily a cognitive process, Ausubel (1968) proposed the idea of meaningful learning which provides practical advice on how cognitive structures within the human mind can be utilized in classrooms to build deep understanding of topics. A rationalist perspective links to $\mathrm{CI}$ through the argument that complex concepts and deep thinking can be best grasped when taught through integrated means. Supporters reason that CI facilitates intellectual development by organizing classroom curricula around big ideas. From a rationalist perspective, a big idea is an overarching concept or theme which helps students make sense of many individual experiences and isolated bits of knowledge (Drake, 1998).

Supporters of this perspective also assert that CI deepens the learning experience by providing students "with opportunities to engage with and make sense of these ideas in learning communities, to problem-solve and, importantly, to act thoughtfully on new understandings" (Wallace et al., 2010, p. 189).

A deeper analysis of a rationalist perspective reveals that knowledge takes on the meaning of deep, contemplative wisdom (theoria). While seemingly similar to the epistemological views of a sociocultural perspective, it is important to note that the universal, unitary view of knowledge supported by rationalists is quite different from the holistic view that a sociocultural perspective draws from. Where holism actively supports the notion that knowledge may be derived from many sources (mental, physical and spiritual) to form a.

seamless whole, a unitary universal view suggests only one truth exists which can be derived by anyone through cognitive rational processes. Explaining further, in holistic theory, persons are viewed as physical, cognitive, emotional, and spiritual beings. The necessity of educating through all of these avenues is encouraged.

However, rationalist cognitivists tend to focus on knowledge and education as mainly cognitive phenomena, originating and developing in the minds of people. They tend to remain silent particularly regarding the possible existence of spiritual sources of knowledge and their use as avenues for education. With respect to this perspective's understanding of the relationship between curriculum and society and 
its curricular interest (Habermas, 1971), there is some difficulty in making easy categorizations. This is of great significance because supporters of a rationalist perspective tend to be silent regarding the populist sociopolitical positions they hold.

While it is clear that, they are concerned about transforming society, they do not seem willing to use activist political language in the same way as supporters of the democratic and environmental perspectives. They claim to be more concerned with developing wise, thoughtful people, who will in time naturally change society for the better. But at the same time, they tend to also remain silent on exactly what it means to be good and wise. In other words, it would seem that knowledge and reason are in themselves sufficient to transform society since, in the rationalist's opinion, knowledge and goodness are inherently intertwined in powerful ways. The curricular interest, then, may be classified as both technical and practical: encouraging deep personal understanding of the legitimate canons of knowledge along with the application of these learnings to solve practical problems and communicate with others in meaningful personal ways.

\section{Analysis of Perspectives: Distinctions and Intersections}

Presented above is a description of the substance of each perspective within the bounds of the arguments of its proponents. A deeper analysis of these descriptions reveals overlapping properties, contradictions and silences between and among perspectives. What follows is an elaboration of these points.

While the perspectives identified were unique, throughout our investigation numerous notable overlapping aspects emerged that blurred the lines between them, so that, while we maintain the distinctiveness of these six perspectives, it necessary to point out these complicating overlaps. For example, a democratic perspective highlights the importance of equity and social justice, insofar as it draws on contemporary democratic theorists within education such as, Apple, Beane, Carr, Delpit, and McLaren, who draw links between the limits that marginalized groups have in truly participating in and benefiting from the democratic rights idealistically upheld in their societies. This argument shares a similar thrust to the environmentalist perspective (particularly the anthropocentrists) who argue that the most disenfranchised segments of our society are those that are most vulnerable during environmental catastrophes.

This understanding of environmental justice illustrates how an environmental perspective overlaps with a democratic perspective through its connection to social justice.

A democratic perspective may also be seen to overlap with a sociocultural perspective. Whereas the participatory emphasis of a democratic perspective encourages learners to engage with the knowledge they are being taught, a sociocultural perspective views knowledge as constructed and encourages students to play an active role in its construction. Both perspectives recognize the social aspect of knowledge construction and view integration as a natural outcome of the social construction of learning. The existence of overlaps holds the potential for agreement among the various supporters of CI, but this potential is limited by the contradictions and silences among the perspectives.

In addition to overlaps, there are also numerous contradictions between perspectives especially in terms of their educational aims, curricula contents, epistemological standpoints, and broader political agendas. To illustrate, we discuss some of the main contradictions in the use of the term "real-world" and the nature of knowledge (epistemology) grounding each perspective. A sociocultural perspective seems to overlap with an economic perspective and an environmental perspective, in that all three perspectives perceive knowledge as holistic, that is, broad and interconnected, contrary to hierarchical, positivist, or anthro/Euro-centrist traditions. All three perspectives also emphasize the teaching of real-world knowledge.

But the meaning of real-world in each perspective is different. This is possible because "real-world" is a notoriously vague term that is malleable and often used for persuasive purposes. While the term 
real-world is generally used to invoke a sense of what is tangible, actual, or practical as opposed to that which is idealized, abstract, or theoretical, consensus on what is actual or real is widely debated. In particular, on the topic of knowledge and curriculum, this becomes a question of ontology, in which fundamental questions are asked about the nature of reality, such as: What is real? What is true? For example, while a sociocultural perspective suggests that the curriculum students take-up should mirror their real lives, including understandings of how to navigate the social world, how to stay financially afloat (Charters, 1923), and how to manage the requirements of life; an economic perspective interprets real-world more narrowly as congruent with the economic growth of local jurisdictions. Additionally, advocates of the environmental perspective might argue that the real-world is that which exists beyond the social constructions of society; the earth, including its essence and networks of life, are real aspects. Pragmatic advocates of CI also refer to the real-world needs, but in their case, they are referring to the realities of curriculum delivery in an increasingly demanding, complex, and resource stretched school environment. $\mathrm{CI}$ is rationalized as a pragmatic way to respond to these stresses of the "real-world". This controversy about the term, real-world, reveals a larger issue. In our work, an understanding of the nature of knowledge was one of the major criteria we used in distinguishing the various perspectives. It also turned out to be one of the greatest sources of contradiction between perspectives as well.

For some perspectives (democratic, sociocultural and environmental), knowledge is not fixed but socially, experientially and/or politically constructed, while, for others, it is a stable, universally fixed construct. What counts as valuable knowledge is another important concern of some perspectives. For example, for supporters of an economic perspective financial knowledge is the most valuable knowledge while rationalists equate valuable knowledge with deep contemplative wisdom of the ages. While socioculturalists might claim that democratic approaches depend on the "will of the people", others would argue that democracy is better served by prioritizing scientific and technological knowledge in decision-making (Collins \& Evans, 2017). Varying epistemological understandings has practical ramifications for the manifestation of CI since they determine the aims of programs and the pedagogies used in enacting them.

To complicate matters further, a closer inspection of each perspective reveals the silences within perspectives, that is to say, what is not expounded upon by their supporters. These silences tend to run along the lines of Habermas' (1971) categorization of curricular interests as having technical, practical and critical orientations. For example, while the critical orientations of the democratic and environmental perspective endorse $\mathrm{CI}$ for its ethical, moral, and liberating possibilities, they offer less in terms of pragmatic solutions, particularly in relation to the realities, stressors, and limitations associated with classroom teaching that are commonplace in contemporary schooling. On the other hand, while the sociocultural and pragmatic perspectives are practically oriented, they have little to say about the normative aims for curriculum delivery linked to a broader goal or theory of education, such as what is best for learning, and what might promote an ethical, just, and moral society. These latter perspectives are also silent about their stance on the political dimensions of education-on solutions to problems of institutional racism, of the inequalities exposed by the global health pandemic.

The final problematic silence we have chosen to highlight comes from the technical orientation to learning of a rationalist perspective. Supporters of this perspective remain strongly biased toward cognitivism as a mode of learning despite growing evidence regarding holistic ways of learning. Silences like these within perspectives widen gaps and serve to isolate various supporters of CI into island camps.

In elucidating the overlaps, contradictions, and silences of the various perspectives on CI, it became clear to us that integrated curricula, like disciplinary curricula are also subject to epistemological decisions as to what is included and what is not, how integration takes place and how it does not, and what is worth knowing and what is not. It also became apparent that the trend towards integration of curriculum for teaching and schooling is less a result of findings based on empirical research or considerations of deep learning, and more due to the benefit it provides to those in positions to make, 
shape, and influence what happens in the classroom. For us, this posed a significant challenge to the simple binary classification of integrated versus disciplinary curricula as suggested by Bernstein and led us to consider how this false binary could be overcome by educators interested in achieving deep learning to transform societies.

\section{Moving Beyond the Integration and Disciplinary Boundary Debates Through a Worldly Perspective}

In Bernstein's portrayal of curriculum and power, disciplinary curricula have been shown to maintain structures of power and control that mirror those in larger society. It is our assertion that, whether curriculum is packaged with strong frames within disciplines or weaker integrated frames, it is less of a question of which presentation of knowledge is more beneficial for student learning but rather more a question of the powerful political interests that preserve the particular arrangement of curricular classification. Several contributions since "On the classification of educational knowledge" (1971) have explored how best to address the power dimensions of curricula. Maton (2013), for example, investigates organizing principles of knowledge, building on Bernstein's frameworks through the development of legitimation code theory. Bleazby (2015) proposes that curricular interests might be mitigated by reclassifying knowledge in school settings. A common theme among many of these contributions illustrates that a frequent response to the recognition of power is to attempt to diminish, decrease, or reduce it in some fashion.

In our work, we foreground the ways that teachers and students are able to assume some degree of agency over curriculum, despite the power enmeshed within its classification. We propose that power and control become issues of pedagogy, the domain of teachers and learners. Rather than being confined to either integrated or disciplinary paradigms, we highlight teachers' abilities to command the delivery of knowledge in ways that enable the best learning for students. Bernstein referred to this domain as the framing of educational knowledge, which has much to do with the form of the context in which knowledge is transmitted and received, that is to say, the degree of control that the teacher and pupil possess over the selection, organization and pacing of the knowledge. As Beane (1997) suggests:

The disciplines of knowledge include a great deal (but not all) of what we know about ourselves and our world, ways of making meaning and of communicating those meanings. Thus, authentic curriculum integration, involving as it does the search for self and social meaning, must take the disciplines of knowledge seriously. (p. 38).

Numerous scholars over recent years have observed ways in which the framing of knowledge can be achieved through teacher agency. McPhail (2018), for example, concludes that CI is a useful supplementary opportunity to a disciplinary foundation in secondary schools. Similarly, Pountney and McPhail (2019) propose a "3 Futures model" that bridges knowledge-led disciplinary methods and learner-engaged integrated framework through a "whole-school approach". When the teacher and the learner-not the curriculum - have control over the packaging and the delivery of knowledge, interests become secondary, and student learning becomes paramount. In this way, we recognize that teachers are professionals who make qualified decisions about knowledge in their teaching contexts (Giroux, 1983).

A further pedagogical response within this Foucauldian notion of power is a "Worldly Perspective" (Rennie et al., 2012a, b, 2020, capitalized in original). A Worldly Perspective is one in which the integrated and disciplinary paradigms are considered together. It accepts that many sources of knowledge exist and acknowledges that both theory and experience are necessary to guide education and teachers' actions in classrooms. Through a Worldly Perspective, individual interests may or may not be legitimatized, not according to politically motivated ideologies, but according to the ability of 
their associated pedagogies to provide insight into and understanding of a concept or topic. The Worldly Perspective de-emphasizes the needless binary created between subject orientations and integrated approaches to knowledge, thereby legitimizes the existence of various approaches to curriculum design. Further, this perspective works to bridge different knowledge systems, balancing integrated with disciplinary approaches, connecting local and global issues, and reconciling Western with other knowledge forms. In their own work, Rennie et al. (2012b) propose that, by "adopting a Worldly Perspective, we do not conclude that one approach was better than the other, merely that they were different and that the differences can largely be attributed to educational context" (p. 70). In fact, from a Worldly Perspective, it is necessary that the integrated paradigm and the disciplinary paradigm be considered together, overlapping rather than mutually exclusive. Through a Worldly Perspective, the disciplines exist, but they are omnipresent rather than omnipotent. Worldly knowledge draws from, but is not bounded by, the constraints of traditional disciplines and serves multiple curricular interests.

Teachers who embody the Worldly Perspective understand the inherent connectivity of knowledge, but they also recognize that curriculum has interests. These educators consider the optimal ways for learning and appreciate the strengths of teaching and learning through the disciplines. They also appreciate that learners make deep connections through an integrated curriculum. As Wallace et al. (2010) purport:

Our view is that curriculum integration embraces many forms and many interests. We call this a worldly perspective on integration (Venville et al., 2002), which we believe reflects a holistic or unitary view of knowledge. This perspective recognizes the legitimacy and importance of the different curriculum forms and interests and their contribution to knowledge. A worldly perspective also invites teachers and students to view the curriculum from whole to part, with big issues, concerns, or interests becoming the organising framework rather than serving as illustrations of disciplinary concepts. (p. 200).

Indeed, teachers who work from a Worldly Perspective choose approaches within the disciplinary tradition when appropriate, and integrate when and where it is most suitable, often with some combination of both. They move between disciplinary and integrated approaches in their teaching in seamless ways that benefit student learning. They work through the problem that Bernstein (1971) raises, "Because of the hierarchical ordering of the knowledge in time, certain questions raised may not enter into a particular frame" (p. 375) by asking themselves questions such as: What is lost and what is gained when integrating curriculum? What is lost and what is gained by a disciplinary approach? What breadth to curriculum is lost in a disciplinary framing? What depths to curriculum are not examined in an integration scenario?

\section{Conclusion}

In this article, we revisited Basil Bernstein's (1971) proposition that curriculum packaging and distribution had evolved in such a way that privileged disciplinary approaches in classification and framing. Over the past half-century, growing preferences toward curriculum integration caused us to question the motives and interests that lay behind these developments. Accordingly, we reviewed relevant bodies of literature and through our analyses, propose six categories of interests that help explain the maintenance of $\mathrm{CI}$ as a popular approach to packaging and distributing knowledge. Accordingly, we have suggested how to move towards a deeper understanding and valuing of the ways that knowledge is packaged by acknowledging the limits, overlaps, silences, and contradictions associated with the interests that support curriculum integration, and proposing that a Worldly Perspective as an approach to moving forward in our quest for a better education in the STEM fields. 
In our opinion, what remains important is for STEM educators to recognize the context in which curriculum paradigms and perspectives operate, disregard any benefits based solely on self-strengthening or other unsubstantiated bases, and weigh the outcome of knowledge dissemination-whether integrated or bound within its discipline-according to the micro-context of their students' learning situations. In sum, a Worldly Perspective recognizes the power for learning that not only is behind the disciplinary methods but also sees that curriculum integration may be useful in both helping prepare learners for the current reality, and for an idealized more sustainable world, without exclusion of the other.

Acknowledgements In preparing this analysis, we acknowledge the contribution of colleagues Leonie Rennie and Grady Venville, whose collaboration and friendship over many years have been major sources of inspiration for our work on curriculum integration. We would also like to thank Faith Visentin for locating and assembling a useful foundation of current literature related to curriculum integration.

\section{References}

Adekunle, J.O. (2000). Education. In T. Falola (Ed.), Africa volume 2: African cultures and societies before 1885 (p. 59-72). Carolina Academic Press.

Alsop, S., \& Hoeg, D. (2020). Collegial Conversations at a Time of COVID-19. Journal for Activist Science and Technology Education, 11(2), 60-74.

Apple, M. (2004). Ideology and curriculum ( $3^{\text {rd }}$ ed.). RoutledgeFalmer.

Applebee, A.N., Adler, M., \& Flihan, S. (2007). Interdisciplinary curricula in middle and high school classrooms: Case studies of approaches to curriculum and instruction. American Educational Research Journal, 44(4), 1002-1039.

Asante, M.K. (1991). The Afrocentric idea in education. Journal of Negro Education, 60(2), 170-180.

Ausubel, D. (1968). Educational psychology: A cognitive view. Holt, Rinehart \& Winston.

Beane, J. A. (1997). Curriculum integration: Designing the core of democratic education. Teachers College Press.

Beane, J.A. (2005). A reason to teach: Creating classrooms of dignity and hope. Heinemann.

Beane, J.A., \& Apple, M. (1995). Democratic schools. Alexandria: Association for Supervision and Curriculum Development.

Becker, G.S. (1993). Human capital: A theoretical and empirical analysis, with special reference to education ( $3^{\text {rd }}$ ed.). University of Chicago Press.

Bernstein, B. (1971). On the classification and framing of educational knowledge. In R. Brown (Ed.), Knowledge, Education, and Cultural Change - Papers on the Sociology of Education (pp. 363-392). Tavistock.

Bernstein, B. (2000). Pedagogy, symbolic control and identity (Revised ed.). Rowman \& Littlefield.

Bleazby, J. (2015). Why some school subjects have a higher status than others: The epistemology of the traditional curriculum hierarchy. Oxford Review of Education, 41(5), 671-689.

Bobbitt, F. (1918). The curriculum. Houghton Mifflin.

Bowers, C. (2008). Why a critical pedagogy of place is an oxymoron. Environmental Education Research, 14(3), $325-335$.

Bowles, S., \& Gintis, H. (1975). "The problem with human capital theory-A Marxian critique". American Economic Review, 65(2), 74-82.

Brinegar, K., \& Bishop, P. A. (2011). Student learning and engagement in the context of curriculum integration. Middle Grades Research Journal, 6(4), 207-223.

Brown, D. F. (2011). Curriculum integration: Meaningful learning based on students' questions. Middle Grades Research Journal, 6(4), 193-207

Bruner, J. S. (1984). In search of mind: Essays in autobiography. Harper Collins.

Cajete, G. (2000). Native Science: Natural Laws of Interdependence. Clear Light Publishers.

Carr, P. R. (2008). Educating for democracy: With or without social justice? Teacher Education Quarterly, Fall, 117-136.

Carter, L. (2017). Neoliberalism and STEM education: Some Australian policy discourse. Canadian Journal of Science, Mathematics and Technology Education, 17(4), 247-257.

Cassirer, E. (1951). Philosophy of the enlightenment.: Princeton University Press.

Castro, A. J., \& Knowles, R. T. (2017). Democratic Citizenship Education. The Wiley handbook of social studies research, 287.

Charters, W. (1923). Curriculum construction. Macmillan.

Collins, H., \& Evans, R. (2017). Why democracies need science. John Wiley \& Sons

Court, D. (1991). Teaching critical thinking. The Social Studies, 82(3), 115-119.

Dei, G. J. S. (2002). Leaning culture, spirituality and local knowledge: Implications for African schooling. International Review of Education, 48(5), 335-360.

Delpit, L. (1995). Other people's children: Cultural conflict in the classroom. New York Press. 
Dewey, J. (1916). Democracy and education: An introduction to the philosophy of education.:Macmillan.

Dillon, J., \& Avraamidou, L. (2020). Towards a Viable Response to COVID-19 from the Science Education Community. Journal for Activist Science and Technology Education, 11(2), 1- 6.

Drake, S. (1998). Creating integrated curriculum: Proven ways to increase student learning. Sage.

Freire, P. (1970). Pedagogy of the oppressed. Herder and Herder.

Gallagher, T. L., \& Fazio, X. (2019). Multiple layers: Education faculty reflecting on design- based research focused on curricular integration. Qualitative Research in Education, 8(1), 27-59.

Giroux, H. (1983). Ideology, culture and the process of schooling. Temple University Press.

Gruenewald, D. A. (2004). A Foucauldian analysis of environmental education: Toward the socioecological challenge of the Earth Charter. Curriculum Inquiry, 34(2), 71-107.

Habermas, J. (1971). Knowledge and human interests. (J. J. Shapiro, Trans.). Beacon.

Hanvey, R. G. (1976). An attainable global perspective. Center for Teaching International Relations.

Hargreaves, A., Earl, L., Moore, S., \& Manning, S. (2002). Learning to change: Teaching beyond subjects and standards. Jossey-Bass.

Harvey, D. (2005). A brief history of neoliberalism. Oxford University Press.

Henderson, B. (2011, Fall). Editor's Log. Pathways: The Ontario Journal of Outdoor Education, 24(1), 2.

Henderson, J. G., \& Kesson, K. R. (2004). Curriculum wisdom: Educational decisions in democratic societies. Pearson Education.

Hungerford, H. R., Peyton, R. B., \& Wilke, R. (1983). Editorial-Yes EE does have a definition and structure. Journal of Environmental Education, 7(3), 21-26.

Hunter J. (2011). 21 $1^{\text {st }}$ century skills: Are we succeeding in preparing Ontario's students? EQAO Connects, 2, 3-6.

Hutchins, R. M. (1953). The conflict in education. Harper \& Row.

Jacobs, J. A. (2014). In defense of disciplines: Interdisciplinarity and specialization in the research university. University of Chicago Press.

Kahn, R. (2008). From education for sustainable development to ecopedagogy: Sustaining capitalism to sustaining life? Green Theory and Praxis: The Journal of Ecopedagogy, 4(1), 1-14.

Kant, I. (1992). Theoretical philosophy 1755-1770: The Cambridge edition of the works of Immanuel Kant. Cambridge University Press.

King, T. (2005). The Truth about Stories: A Native Narrative. 2003. University of Minnesota Press.

Leonardo, Z. (2004). Theme issue: Disciplinary knowledge and quality education: Editor's introduction. Educational Researcher, 33(5), 3-5.

Linney, G. (2014). Journeys into relation: Vignettes of OEE-based integrated curriculum programs in Ontario secondary schools. The Council of Outdoor Educators of Ontario.

Martin, I., Crowther, J., \& Shaw M. (2008). Learning for democracy: Ten propositions and ten proposals. Learning for Democracy Group. https://teachnorthern.files.wordpress.com/2015/11/learning-for-democracy-proposals.pdf

Maton, K. (2013). Knowledge and knowers: Towards a realist sociology of education. Routledge.

McCall, S., Reder, D., Gaertner, D., \& Hill, G. L. H. (Eds.). (2017). Read, Listen, Tell: Indigenous Stories from Turtle Island. Wilfrid Laurier Univ. Press.

McLaren, P. (1998). Life in schools. Longman.

McPhail, G. (2018). Curriculum integration in the senior secondary school: A case study in a national assessment context. Journal of Curriculum Studies, 50(1), 56-76.

Miller, J. (2007). The holistic curriculum ( $2^{\text {nd }}$ ed.). University of Toronto Press.

Miller, J., \& Seller, W. (1985). Curriculum: Perspectives and practice. Longman.

Mirowski, P., \& Plehwe, D. (2009). The road from Mont Pèlerin: The making of the neoliberal thought collective. Harvard University Press.

Montessori, M. (1912). The Montessori method. (A. Everett, Trans.). Fredrick A. Stokes Company.

Morreale, C., \& Zile-Tamsen, V. (2017). Thinking Skills by Design: Using a Capstone ePortfolio to Promote Reflection, Critical Thinking, and Curriculum Integration. International Journal of ePortfolio, 7(1), 13-28.

Moss, J., Godinho, S.C., \& Chao, E. (2019). Enacting the Australian curriculum: Primary and secondary teachers' approaches to integrating the curriculum. The Australian Journal of Teacher Education, 44(3).

Naess, A. (1988). Deep ecology and ultimate premises. Ecologist, 18(4-5), 128-131.

Nazir J., \& Pedretti E. (2018). Environmental education as/for environmental consciousness raising: Insights from an Ontario outdoor education centre. In G. Reis, J. \& Scott (Eds.), International Perspectives on the Theory and Practice of Environmental Education: A Reader. Environmental Discourses in Science Education, 3, 85-98. Springer.

Ng-A-Fook, N. (2013). Fishing for knowledge beyond colonial disciplines: Curriculum, social action projects, and indigenous communities. In Contemporary studies in environmental and indigenous pedagogies (pp. 285-305). Brill Sense.

Ollila, J., \& Macy, M. (2019). Social studies curriculum integration in elementary classrooms: A case study on a Pennsylvania Rural School. The Journal of Social Studies Research, 43(1), 33-45. 
Park, T., Pearson, D., \& Richardson, G. B. (2017). Curriculum Integration: Helping Career and Technical Education Students Truly Develop College and Career Readiness. Peabody Journal of Education, 92(2), 192-208.

Pate, E., \& Nesin, G. (2011). Teaching about and through curriculum integration: How two university professors organize their curriculum. Middle Grades Research Journal, 6(4), 235-245.

Pountney, R., \& McPhail, G. (2019). Crossing boundaries: Exploring the theory, practice and possibility of a 'Future 3'curriculum. British Educational Research Journal, 45(3), 483- 501.

Ravetz, J. (2005). The no-nonsense guide to science. New Internationalist.

Rennie, L., Venville, G. \& Wallace, J. (Eds.) (2012a). Integrating science, technology, engineering and mathematics: Issues, reflections and ways forward. Routledge.

Rennie, L., Venville, G. \& Wallace, J. (2012b). Knowledge that counts in a global community: Exploring the contribution of integrated curriculum. Routledge.

Rennie, L.J., Venville, G., \& Wallace, J. (2020). A worldly perspective. Applying theory to STEM education. In C. Johnson, M. Mohr-Schroeder \& T. Moore (Eds.), Handbook of Research in STEM Education (pp. 39-50). Routledge.

Robottom, I. (2012). Socio-scientific issues in education: Innovative practices and contending epistemologies. Research in Science Education, 42, 95-107.

Ross, J. A., \& Hogaboam-Gray, A (1998). Integrating mathematics, science and technology: Effects on students. International Journal of Science Education, 20(9), 1119-1135.

Sant, E. (2019). Democratic education: a theoretical review (2006-2017). Review of Educational Research, 89(5), 655-696.

Sauvé, L. (2005). Currents in environmental education: Mapping a complex and evolving pedagogical field. Canadian Journal of Environmental Education, 10, 11-37.

Schwab, J., \& Rainey, W. (1970). The practical: A language for curriculum. National Center for the Study of Instruction.

Sen, A. (2009). The idea of justice. Harvard University Press.

Shanahan, M-C, Burke, L. C-A., \& Francis, K. (2016). Using a boundary object perspective to reconsider the meaning of STEM in a Canadian context. Journal of Science, Mathematics and Technology Education, 16(2), 129-139.

Shriner, M., Schlee, B. M., \& Libler, R. (2010). Teachers' perceptions, attitudes and beliefs regarding curriculum integration. The Australian Educational Researcher, 37(1), 51-62.

Smith, L. T. (1999). Decolonizing methodologies: Research and indigenous peoples. Zed Books Ltd.

Spiller, P. (2017). Could subjects soon be a thing of the past in Finland? BBC News, Finland. https://www.bbc.com/news/ world-europe-39889523.

Steger, M. B., \& Roy, R. K. (2010). Neoliberalism: A very short introduction. Oxford University Press.

Steiner, R. (1965). Theosophy: An introduction to the supersensible knowledge of the world and the destination of man. (M. Cotterell \& A. P. Shepherd, Trans.). K. Paul Trench.

Stevens, R., Wineburg, S., Herrenkohl, L. R., \& Bell, P. (2005). Comparative understanding of school subjects: Past, present, and future. Review of Educational Research, 75(2), 125- 157.

Stronge, J.H. (2002). Qualities of effective teachers. ASCD.

Thorburn, M. (2017). Dewey, democracy, and interdisciplinary learning: a Scottish perspective. Oxford Review of Education, 43(2), 242-254.

Tyler, R. (1949). Basic principles of curriculum and instruction. University of Chicago Press.

UNESCO. (1975). The international workshop on environmental education final report, Belgrade, Yugoslavia. UNESCO/ UNEP.

Vars, G.F. (1991). Integrated curriculum in historical perspective. In Abstracts International, 20, 1830-1831.

Venville, G., Sheffield, R., Rennie, L., \& Wallace, J. (2008). The writing on the wall: Classroom context, curriculum implementation, and student learning in integrated, community-based science projects. Journal of Research in Science Education, 45(8), 857-880.

Venville, G., Wallace, J., Rennie, L., \& Malone, J. A. (2002). Curriculum integration: Eroding the high ground on science as a school subject? Studies in Science Education, 37(1), 43-83.

Wallace, J., Sheffield, R., Rennie, L., \& Venville, G. (2007). Looking back, looking forward: Re-searching the conditions for curriculum integration in middle years of schooling. The Australian Educational Researcher, 34(2), 29-49.

Wallace, J., Venville, G., \& Rennie, L. (2010). Integrated curriculum. In D. Pendergast \& N. Bahr (Eds.), Teaching middle years: Rethinking curriculum, pedagogy and assessment (pp. 188-204). Allen \& Unwin.

Wals, A. E. J., Stevenson, R. B., Brody, M., \& Dillon, J. (2013). Tentative directions for environmental education research in uncertain times (pp. 542-548). In R. B. Stevenson,

Westheimer, J. (2015). What kind of citizen?: Educating our children for the common good. Teachers College Press.

White, L. (1967). The historical roots of our ecological crisis. Science, 155, 1203-1207.

Wotherspoon, T. (2004). The sociology of education in Canada: Critical perspectives (2 ${ }^{\text {nd }}$ ed.). Oxford University Press.

Publisher's Note Springer Nature remains neutral with regard to jurisdictional claims in published maps and institutional affiliations. 